IZA DP No. 7506

Financial Support for Families with Children and its Trade-offs: Balancing Redistribution and Parental Work Incentives

Michał Myck

Anna Kurowska

Michat Kundera

July 2013 


\title{
Financial Support for Families with Children and its Trade-offs: Balancing Redistribution and Parental Work Incentives
}

\author{
Michał Myck \\ CenEA, DIW Berlin and IZA
}

Anna Kurowska

University of Warsaw

Michał Kundera

CenEA

Discussion Paper No. 7506

July 2013

IZA

P.O. Box 7240

53072 Bonn

Germany

Phone: +49-228-3894-0

Fax: +49-228-3894-180

E-mail: iza@iza.org

\begin{abstract}
Any opinions expressed here are those of the author(s) and not those of IZA. Research published in this series may include views on policy, but the institute itself takes no institutional policy positions. The IZA research network is committed to the IZA Guiding Principles of Research Integrity.

The Institute for the Study of Labor (IZA) in Bonn is a local and virtual international research center and a place of communication between science, politics and business. IZA is an independent nonprofit organization supported by Deutsche Post Foundation. The center is associated with the University of Bonn and offers a stimulating research environment through its international network, workshops and conferences, data service, project support, research visits and doctoral program. IZA engages in (i) original and internationally competitive research in all fields of labor economics, (ii) development of policy concepts, and (iii) dissemination of research results and concepts to the interested public.
\end{abstract}

IZA Discussion Papers often represent preliminary work and are circulated to encourage discussion. Citation of such a paper should account for its provisional character. A revised version may be available directly from the author. 


\section{ABSTRACT}

\section{Financial Support for Families with Children and its Trade-offs: Balancing Redistribution and Parental Work Incentives ${ }^{1}$}

Financial support for families with children implies inherent trade-offs some of which are less obvious than others. In the end these trade-offs determine the effectiveness of policy with respect to the material situation of families and employment of their parents. We analyse several kinds of trade-offs involved using a careful selection of potential changes to the system of financial support for families with children. We focus on: 1) the trade-off between redistribution of income to poorer households and improving work incentives, 2) the trade-off between improving work incentives for first and for second earners in couples, 3) the trade-off between improving work incentives for those facing strong and weak incentives in the baseline system. The exercise is conducted on data from Poland, a country characterized by high levels of child poverty, low female employment and one of the lowest fertility rates in Europe. We demonstrate the complexity of potential consequences of family support policy and stress the need for well-defined policy goals and careful analysis ahead of any reform.

JEL Classification: J22, J13, J18

Keywords: labour supply, tax and benefit reforms, microsimulation, family policy

Corresponding author:

Michał Myck

Centre for Economic Analysis, CenEA

ul. Królowej Korony Polskiej 25

70-486 Szczecin

Poland

E-mail: mmyck@cenea.org.pl

\footnotetext{
${ }^{1}$ The paper was written with financial support from the Foundation for Polish Science (Parent-Bridge Programme) as part of the project "Joint influences of family and labour market policies on labour market participation and fertility decisions of men and women" coordinated by Anna Kurowska. Data used in the analysis has been provided by the Polish Central Statistical Office (GUS), who take no responsibility for the analysis and interpretation of the results. We are grateful to Katharina Wrohlich and Irena Kotowska for detailed comments on an early draft of the paper. The usual disclaimer applies.
} 


\section{Introduction}

While financial support for families with children is often portrayed as a single package, the policy objectives behind it imply inherent contradictions and implicit trade-offs. In this paper we present the complex nature of consequences of different forms of financial support and analyse them in the light of distributional and labour market implications. The analysis is conducted with reference to the Polish system of support for families with children, but its conclusions extend beyond the specificity of the Polish circumstances and provide guidance to policy making in systems of financial support more generally.

Financial support for families with children is an important and integral part of the broad family policy package, the goals of which fall into three basic categories of reducing child poverty, increasing labour market activity of parents and ensuring demographic stability through high fertility rates (see e.g. Whiteford and Adema, 2007; Björklund, 2006; Immervoll, et al., 2001; Thévenon and Luci, 2012; Europa 2020). However, particular policy aimed at one of these objectives, may be detrimental to the achievement of the other goals. For example, family/child benefits may directly increase family income and thus reduce child poverty (see e.g. Whiteford and Adema, 2007; Immervoll, et al., 2001). At the same time these same benefits however, could have negative effect on parental incentives to work, particularly for the so-called second earners, usually mothers (see e.g. Laroque and Salanie, 2008; Kornstad and Thoresen, 2007; Haan and Wrohlich, 2011). Benefits and low employment among mothers might positively affect timing of childbirth and influence fertility (Laroque and Salanie, 2008; Matysiak and Vignoli, 2008; Gauthier, 2007; Duclos, et al., 2001). On the other hand, though, employment of both parents often turns out to be crucial for long term poverty reduction (Whiteford and Adema, 2007) and in some cases it's also a precondition for fertility decisions (Matysiak, 2011; Fiori et al., 2013).

Specific policy solutions focused on child poverty and employment contain implicit trade-offs (Blundell 2001; Immervoll et al. 2007), which are often poorly understood or treated superficially in the policy debate. The effect of such lack of understanding may result in badly designed policy 
reactions to identified problems and this may imply that one of the objectives is achieved at the cost of the other, or even that the policies work against all of them.

In this paper, using the Polish microsimulation model SIMPL, we simulate modification of several elements of the Polish tax and benefit system to demonstrate the complex nature of tradeoffs on the one hand between incomes and employment policy, and on the other, within employment policy itself. The underlying assumption of the analysis is that any effective policy which aims at lower child poverty and higher fertility in the long run ought to realize and address the issues of parental labour market activity. ${ }^{2}$ Governments should therefore aim at such design of the financial support for families which provides assistance to poor households and at the same time strong work incentives for parents. The analysis is conducted on the background of significant demographic challenges facing Poland in the coming decades due to very low fertility rates, as well as a combination of high child poverty and low female employment in particular among mothers. Poland has currently one of the lowest fertility rates in the world and by 2050 is expected to face the old-age dependency ratio of 53\%. At the same time according to EUROSTAT (2011) 29.1\% of children in Poland are at risk of poverty or social exclusion, ${ }^{3}$ and the male-female employment gap is 12.5 percentage points. ${ }^{4}$ Importantly, the employment gap is as low as 1,8 percentage points, among childless people, but grows to 31.6 percentage points for parents of two or more children aged below 6. There is also a clear relationship between work and poverty in Poland. Child poverty in high work intensity households is only $8.2 \%$, and it grows to $30.3 \%$ among medium work intensity households and to $50.6 \%$ for those with low intensity. ${ }^{5}$

The starting point for the analysis is a reform of a particular feature of the design of Family Benefits, the main channel of financial support for families with children in Poland, namely the point withdrawal of benefits once income exceeds the means-test eligibility threshold. The proposed tapered withdrawal of benefits serves as a cost benchmark for four other reforms - two further changes in the system of Family Benefits, and two reforms of the Child Tax Credit, the

\footnotetext{
${ }^{2}$ Note that this assumption is not at odds with parental preferences concerning taking time off work to take care of children when they are young (Kotowska, et al., 2009; Hakim, 2003).

${ }^{3}$ The share of population living below $60 \%$ of national median equivalised disposable income.

${ }^{4}$ The difference in the employment rates for men and women (20-49 years old). Source: EUROSTAT.

${ }^{5}$ Work intensity of a household is the ratio of the total number of months that all working-age household members have worked during the income reference year to the total number of months the same household members theoretically could have worked in the same period. Households with work intensity in the range of 0,85-1,00 are considered high work intensity, those with intensity in the range of 0,45-0,55 are medium intensity, and those below 0,45 low intensity households. Source: Eurostat statistical database for 2011.
} 
second largest instrument of child support. These five reforms are designed in such a way as to demonstrate the nature and the degree of trade-offs implied by financial support for families. The principal trade-offs we discuss are:

a) the trade-off between redistribution of income to poorer households and improving work incentives;

b) the trade-off between improving work incentives for first and for second earners in couples;

c) the trade-off between improving work incentives for those facing strong and weak incentives in the baseline system.

The most important trade-offs related to the support of low-income families and its consequences on the labour market have been known for long (see e.g. Duncan and Giles, 1996; Blundell et al. 2000; Immervoll and Barber 2006; Immervoll et al. 2007; Adam and Browne 2010; Jara and Tumino 2013). This paper, however, sheds new light on the problem and extends the analysis of the trade-offs involved to issues which have so far been little examined. Apart from the wellestablished trade-off between equity and labour market concerns, we draw the attention to the need to balance out first and second earner work incentives as well as incentives by the degree of existing financial motivation to work.

The simulated implications of the reforms provide important insights regarding consequences of financial support for families with children and can serve as reference and guidance for numerous policy changes. We demonstrate that policy trade-offs go beyond the simple equity-efficiency concerns. Reforms which provide strong work incentives for first earners are likely to weaken incentives for their partners, and policy changes which seem to address work incentives most effectively focus on groups of the population which may not require additional financial stimuli on the labour market.

The rest of the paper is organised as follows. In Section 2 we describe the main tax and benefit instruments aimed at families with children in Poland. This is followed in Section 3 by a brief discussion of the data we use for the exercise and of labour market differences by family status. On this background we describe the five potential policy interventions in the area of taxes and 
benefits using CenEA's microsimulation model SIMPL (Section 4). ${ }^{6}$ These reforms are designed in such a way as to have different distributional and labour market consequences at the same cost to the government, with the latter determined by the reference reform, namely the tapered withdrawal of family benefits. In Section 5 the reforms are analysed from the point of view of labour market incentives with a focus on couples to examine the three principal trade-offs. The analysis shows the complexity of consequences of family support from the point of view of distributional implications as well as effects on work incentives for first and second earners in couples. We argue that any change in the design of government support for families with children should start from a clear specification of the principal objective it is supposed to achieve. At the same time it should take into account additional consequences the reform will necessarily have in the area of the material situation of families and financial incentives to work for mothers and fathers.

\section{Financial support for families with children in Poland}

In the analysis below we use the Polish Household Budgets' Survey data from 2010 and apply to this the 2010 system of taxes and benefits as the baseline for our reform simulations. In this section we present a brief description of two main instruments of support directed at families with children in Poland, namely the system of Family Benefits and the non-refundable Child Tax Credit in the system of personal income taxation.

In the Polish tax and benefits system market earnings are subject to social security contributions (SSCs) covering pension, disability, sickness, unemployment and accident insurance. The SSCs are paid with reference to individual gross income and are nominally split into the employee and employer side (totalling respectively $13.71 \%$ and $19.13 \%$ ). Retirement and disability pension SSCs are paid only up to the threshold equivalent to 2.5 of total annual average earnings (85,562 PLN in 2010, i.e. $€ 20,617){ }^{7}$ On top of SSCs individuals pay personal income tax at two rates (18\% and 32\%) and health insurance at $9 \%$ of which 7.75pp. is deductible as tax credit from

\footnotetext{
${ }^{6}$ SIMPL is CenEA's microsimulation model for Poland. It is based on the Polish Household Budgets Survey data and allows for detailed calculation of the main elements of the tax and benefit system in Poland. It allows simulating both actual systems and various alternative tax and benefit scenarios and their direct consequences on household incomes. For details concerning the model and for examples of its earlier applications see, e.g. Bargain et al. (2007), Morawski and Myck (2009, 2011), Haan and Myck (2010, 2012).

${ }^{7}$ All monetary values in the paper are given in Polish zloty (PLN). The exchange rate of the euro to PLN in June 2010 was: $€ 1=4.15 P L N$ and we occasionally quote the values in euro alongside the PLN values.
} 
income tax. Taxes and health insurance are paid on income net of the SSCs. Every individual tax payer can claim a universal tax credit of 556.02 PLN (€134) and revenue cost allowance at individual level of 1,334 PLN (€321) is available to earners. Tax splitting (joint taxation) is available to married couples and lone parents, and since 2007 parents can set their tax liabilities against the Child Tax Credit, which is a non-refundable tax credit, the maximum value of which is $1,112.04$ PLN (€268) per year for every dependent child. ${ }^{8}$

The Polish system of support for low income families, the Family Benefits, consists primarily of the Family Allowance (FA) with supplements. These are means-tested and are available to families with net incomes below 504 PLN (€121) per month per person (or 583 PLN if there is a disabled child in the family). The value of the FA depends on the age of the child and ranges from 68 PLN to 98 PLN ( $€ 16.40$ to $€ 23.60$ ) per month. For eligible parents this is supplemented by additional means-tested payments to such groups as lone parents, families with more than two children, and those with school-age children (see Table A1 in the Appendix for a full list of supplements and their 2010 values). Parents of disabled children receive further support through the universal Nursing Allowance and the Nursing Benefit, and there is a universal one-off birth benefit of 1000 PLN (€241).

Eligibility criteria for Family Benefits assess family income with reference to a threshold, which once exceeded makes the family ineligible to claim the benefits. Such point withdrawal of benefits implies very high effective marginal tax rates and has significant implications for average effective rates of tax (see Myck et al., 2013). Although parents who received family benefits in the year preceding the time of application are allowed (only for one year) to exceed the income threshold by the equivalent of the value of a single family allowance, this only shifts the threshold upwards, and implies that the families where income is just above 600 PLN per person would no longer receive the benefits even if their income crosses the increased threshold only by 1 PLN. Eligibility of families whose incomes fall relative to the previous year are assessed with reference to the basic threshold.

This feature of the system is illustrated in Figure 1A where we show the budget constraint for a single earner couple with one, two and three children, and in Figure 1B, which for the same families shows the relationship between gross income and monthly total family support - the sum

\footnotetext{
${ }^{8}$ For details of the Polish tax and benefit system see e.g.: Morawski and Myck (2010, 2011), Domitrz et al. (2013) or Kundera et al. (2012).
} 
of Family Benefits and the CTC. As we can see the combination of these two elements results in similar levels of support given to low and high income families in 2010, while highest amounts are paid to families with incomes just below the FB eligibility threshold where they can claim part of the Child Tax Credit and still receive the full amounts of Family Benefits. For couples with one child this corresponds to gross income of 125.51 PLN per month, while for families with two and three children to 281.45 and 517.39 PLN per month. The point withdrawal of Family Benefits is probably the most peculiar element of the Polish system of family support, and we take a reform of this element through the introduction of a gradual withdrawal taper as a reference scenario for the comparison of other alternative changes to the system of support in Sections 4 and 5.

\section{FIGURE 1 HERE}

As the above description makes clear the Polish tax and benefit system contains no instruments specifically targeted at providing work incentives to second earners in couples. All of the gains available to couples -joint taxation, joint availability of the Child Tax Credit and joint assessment of incomes for Family Benefits, with the particular feature of the point withdrawal of benefits are classic examples of features of the tax and benefit systems, which act to discourage employment of secondary earners in couples through the income effect (e.g. Duncan and Giles, 1996; Blundell et al., 2000; Haan and Myck, 2007; Bargain and Orsini, 2006, Brewer et al., 2006; Immervoll et al., 2011). In the case of parents of pre-school children joint employment involves often substantial childcare costs, which further contributes to the financial disincentives to work for the second earner. Research on the consequences of such features using data for other countries suggests that they play an important role in determining the pattern of employment among couples (Dearing et al., 2007; Steiner and Wrohlich, 2004).

\section{Data used for the analysis and employment of parents in Poland}

\subsection{Data and samples used for the analysis}

Our analysis is based on data from the Polish Household Budget Survey (PHBS) which is conducted annually by the Polish Central Statistical Office and covers detailed information on demographics, incomes and household expenditures. We use the 2010 PHBS database which 
includes information on a representative sample of 37,412 private households (107,967 individuals). For the purpose of our analysis households are divided into families, composed of adults (singles or cohabiting couples) with or without dependent children. There are 51,413 families in the sample. The great majority of households are single-family households (73.1\%), but in about $20 \%$ of households we identify two families and in $16.9 \%$ three or more. ${ }^{9}$

The descriptive statistics for employment presented below focus on families where heads of families and their partners are below retirement age. This limits the sample of families to 38,020 families (73.6\% of all the families in the full sample). We distinguish four basic family types (see Table 1): single individuals without children (37.6\%), couples without children (18.0\%), lone parents (6.4\%), and couples with children (38.0\%). More details concerning the sample used for the employment analysis in Section 3.2 are given in Table A1 in the Appendix.

\section{TABLE 1 HERE}

\section{TABLE 2 HERE}

The analysis of work incentives presented in Section 5 further narrows down the sample as we focus only on couples with children in which both partners are labour market (LM) flexible. LM flexible means that a person is not a student, do not receive disability or retirement pension, is aged between 18-59 and is not. There are 10,109 such families in our sample from the PHBS 2010 data.

\subsection{Employment rates of men and women by family type}

Employment rates of men and women differ significantly according to the distinguished family types, number of children and age of the youngest child. The following analysis presents the most significant differences and relationships that form the background for the analysed policy reforms discussed in Section 4.

As we can see in Table 2 the difference between employment rates for men and women is highest among couples with children. While the employment rates for women are only $2.5 \%$ lower than for men among lone parents and 7.5\% lower among singles without children, for couples without children this difference is $14.6 \%$ and for couples with children it is as high as $24.0 \%$.

\footnotetext{
${ }^{9}$ Throughout the paper percentages computed for the purpose of sample description use sample weights provided by the Polish CSO in the PHBS data.
} 
The difference in employment rates of mothers and fathers in couples is very high when women are in the reproductive age range (up to about 40-45 years old), and in particular at ages when they are likely to have young children (Figure 2A). Employment of women in couples grows among older women with children and from about 40 is actually slightly higher compared to women without children (Figure 2A). Employment rates of men in couples up to the age of about 45-49 is above $80 \%$ and there is little difference between men with and without children. Employment of both men and women in the age groups above 45 begins to fall, but we need to remember that the analysis cannot distinguish age from cohort effects and the lower rates of employment among those age 50+ may be driven by the cohort differences in labour market activity.

\section{FIGURE 2 HERE}

The age of the youngest child has its clear effect on the employment rates of mothers but little consequence for the employment rate of fathers (Figure 2B). Employment rates of mothers (both in couples and lone mothers) grow significantly with age of their youngest child. At the same time employment rate of fathers remains stable up to the age of 12 of their youngest child, and drops slightly when the youngest child becomes older.

\subsection{Employment rates by receipt of family benefits}

It has been long argued that the system of family benefits in Poland is mainly focused on passive poverty reduction and offers little additional incentives to encourage parents to work (e.g. Wóycicka, 2005; Haan, et al., 2008; Kurowska, 2012). This is partly due to the point withdrawal of Family Benefits, but relates also to the overall joint approach to eligibility for family support through benefits and taxes and lack of any employment-related incentives or elements supporting childcare expenditure. This problem has recently worsened as a result of a policy of increasing real benefit values with simultaneous reductions in the real value of eligibility thresholds (e.g. Myck et al. 2011, Domitrz et al. 2013).

The point withdrawal of family benefits is certainly one of the most problematic features of the system from the point of view of labour market incentives. Such approach discourages greater intensity of work and increases in productivity among first earners and implies strong 
disincentives for second earners on the extensive margin. Among couples receiving the benefits only $39.2 \%$ are two-earner couples, and $44.9 \%$ are couples where only the father works. The respective figures for those who do not receive the benefits are $67.8 \%$ and $23.0 \%$ (see Table 3 ).

Such differences are hardly surprising, as entering employment for many of the mothers would result in the loss of benefits (the majority of which are paid directly to the mother). As we argue in Sections 4 and 5 through careful changes to the design of the benefits, some of these mothers could be encouraged to take up employment. As we can see in Table A1 the potential for increasing employment of mothers is particularly high among recipients of Family Benefits with one or two children (56.3\% of single-earner families) and those with children in pre-school age (61.9\%). The statistics confirm the pattern found in other countries of a higher proportion of single-earner families when their youngest child is below school-age. This relates on the one hand to the greater need of parental care among youngest children, but also to childcare costs which have to be born to facilitate employment of both parents.

\section{TABLE 3 HERE}

\section{Reforming financial support for families - design and distributional consequences}

\subsection{Modelled reform options}

The principal goal of the simulations presented in this paper is to analyse the trade-offs involved in different types of changes applied to the main elements of financial support for families in Poland. As mentioned above the starting point for this analysis and a reference in terms of potential costs of the reform, is the move to tapered withdrawal of Family Benefits. For this purpose we use the rate of withdrawal at 55\%, which is the rate used in a broadly studied in-work support program in the UK, the Working Families’ Tax Credit (WFTC) in late 1990s and early 2000s (see, e.g.: Blundell et al., 2000; Brewer et al., 2006; Clark et al., 2002, Haan et al., 2008). Application of such a taper implies that with an increase of net income of 1 PLN beyond the withdrawal threshold, the total value of benefits is reduced by 0.55 PLN. Such a change would imply greater certainty and predictability of benefit receipt, compared to the current point withdrawal system. However, as it extends the availability of benefits to families who currently no longer qualify for them, it would carry additional costs. We estimate this cost to be in the 
range of about 1.04 bn PLN (€250mln) per year, an increase in the total value of family benefits by about $14 \%$.

The withdrawal taper reform (referred to below as System 1) is used as a cost benchmark for four other potential changes to the tax and benefit system designed in such a way as to have different implications for work incentives. First two reforms change the parameters of the Family Benefits system, while the third and fourth change the functioning of the Child Tax Credit. Details of changes implemented in all modelled reform systems are summarized in Table 4 and are presented for stylised households in Figures 3 and 4.

Changes in Family Benefits under System 2 involve simple increases in the values of the Family Allowance, which is raised by $20 \%$ given the cost benchmark of 1.04 bn PLN. The final reform to Family Benefits (System 3) combines the introduction of the withdrawal taper (at 55\%) with a bonus system for two-earner families with the specific aim to provide stronger work incentives for second earners. The bonus consists of an increase in the withdrawal threshold from which Family Benefits begin to be reduced by $50 \%$ compared to the baseline threshold value for families where both parents work. This approach requires a specification of conditions qualifying families for the double-earner status, and we set this in the form of a minimum earnings level for both parents of at least $80 \%$ of the minimum wage (1,054.00 PLN). Since benefit eligibility is assessed on the basis of annual incomes in Poland this requirement could take the form of employment at less than full time minimum wage throughout the year or full time work for part of the year with earnings at or above the minimum wage. The addition of this double earner bonus on top of the 55\% withdrawal taper further increases the costs of the reform. To calibrate them to the benchmark cost of 1.04 bn PLN we reduce the reference income threshold from which Family Benefits begin to be withdrawn by $9.0 \%$.

The first reform of the Child Tax Credit assumes an increase in the value of the CTC by 19.8\% (calibrated to cost 1.04 bn PLN), while the second uses this tax credit instrument to reward the two-earner status. In the latter case, double-earner couples are granted an additional value of the credit (92.70 PLN per month). The cost of this reform is again calibrated to the level of other reforms by adjusting the earnings requirement set for both parents to qualify as double-earner couples. This calibrated requirement is 2,324.50 PLN per month, which is equivalent to $176.5 \%$ of the minimum wage. The effects of the modelled reforms for the values of Family Benefits and 
Child Tax Credit are demonstrated for different stylized households in Figures 3 (Systems 1-3) and 4 (Systems 4 and 5).

\section{TABLE 4 HERE}

Figure 3A presents the effects of changes for a single earner family with two children conditional on the gross earnings of the earner. Under the 2010 baseline system (System 0) the maximum amount of Family Benefits this family can receive is 167.30 PLN (€40.30) per month, and this is paid up to the point when the income from work exceeds the threshold of 504.00 PLN per person which for this family corresponds to the gross earnings of 2,565.00 PLN per month. Introduction of the tapered benefit withdrawal (System 1) extends eligibility to Family Benefits for this family to 2,950.00 PLN. Under System 2 eligibility criteria do not change but families eligible to receive the benefits under the base scenario see their benefit amounts grow due to increases in the Family Allowance. In the case of the Family in Figure 3A the value of Family Benefits grows to 199.20 PLN (€48) per month. The consequences of introducing System 3 with respect to the baseline system imply earlier withdrawal of the benefits (from 2,340.00 PLN per month) given the change of the withdrawal threshold from which benefits begin to be tapered away. However, because of the tapered withdrawal the benefits now extend further up the earnings distribution compared to the baseline scenario. Thus single earner families with gross earnings between 2,340.00 PLN and 2,720.00 PLN per month gain on the introduction of System 3. As Figure 3A makes clear, though, System 1 is more generous than System 3 for single earner families.

The reason for the difference between Systems 1 and 3 in the case of single earner families, given the same cost of the two reforms, is demonstrated in Figure 3B where we demonstrate the effect of the reforms, conditional on the earnings of the second earner and assuming that the first earner receives gross earnings corresponding to $75 \%$ of the mean wage. ${ }^{10}$ In this case the generosity of the baseline and reformed scenarios is shown for a family with three children. As we can see in this case benefits in the baseline System 0 and under System 2 are withdrawn when the second earner's gross earnings reach 785.00 PLN per month. It is worth noting here that under System 2 the family income in the out of work scenario of the second earner is higher relative to the baseline scenario. Family Benefits under System 3 begin to be withdrawn at the gross earnings of the second earner beyond 465.00 PLN per month. However, the system now rewards the double

\footnotetext{
${ }^{10}$ The value of the mean gross wage in 2010 was 3,224.98 PLN per month.
} 
earner status by raising the benefit withdrawal threshold by $50 \%$ once earnings of both partners are at least $80 \%$ of the minimum wage, i.e. 1,054.00 PLN. This means that in the example shown in Figure 3B the family is again eligible to receive the full amount of Family Benefits up to the earnings level of 1,960.00 PLN. From that point benefits are tapered away and families cease to receive them once the earnings of the second earner reach the level of 2,835.00 PLN.

\section{FIGURE 3 HERE}

\section{FIGURE 4 HERE}

In Figure 4 we show the simulated effects of changes in the Child Tax Credit. These are demonstrated for a family with two children in the case of a single earner scenario (Figure 4A) and with respect to earnings of the second earner with the same assumption on earnings of the first earner as in Figure 3B. As we can see from Figure 4A, benefits of the Child Tax Credit begin once earnings of the first earner exceed 1,275.00 PLN per month and for a family with two children the full credit under the baseline scenario is exhausted from earnings beyond 3,370.00 PLN. This implies that the value of the CTC for this example family still grows when the second partner takes up employment and the earnings of the first earner are at the assumed level of $75 \%$ of mean wage (i.e. 2,419.00 PLN, Figure 4B). Thus single earner families with gross earnings beyond 3,370.00 PLN, and the second earner scenario with gross earnings beyond 1,175.00 PLN benefit from introduction of System 4 . The effects of introducing the double earner premium in the CTC (System 5) benefits only the family with the second earner (Figure 4B), and only when the earnings exceed the required threshold of 2,325 PLN (176.5\% of the minimum wage, or $72.1 \%$ of the mean wage). Since the double earner premium in CTC is equivalent to the full CTC amount for every child, the family gains 92.67 PLN (€22.30) per month once the earnings of the second earner exceed the required threshold.

\subsection{Distributional consequences of modelled reforms}

The assumptions underlying the modelled scenarios are very clearly reflected in the (static) distributional effects of the simulated changes. The proportional changes in incomes among families with children by population decile groups resulting from the simulated reforms are demonstrated in Figure 5A for Systems 1-3 and Figure 5B for Systems 4-5. 
The poorest families benefit most under System 2, since it raises the values of the Family Allowance for those who receive it under the baseline scenario. On average incomes of households with children in the bottom decile grow by about 3\% as a result of higher rates of the Family Allowance. System 5, on the other hand, allocates the additional resources primarily to better off households with highest proportional changes in the $9^{\text {th }}$ decile amounting on average to about $0.8 \%$. Increases in the CTC under System 4 are proportionally most generous to middle income families, while Systems 1 and 3 are most generous to families in the $2^{\text {nd }}$, $3^{\text {rd }}$, and $4^{\text {th }}$ decile.

The difference in the distributional effect between systems 1 and 3 is worth noting. Since the benefits of System 3 focus on two-earner families, the reform has negligible effect on poorest households. At the same time it benefits the families in deciles 3,4 and 5 by $1.47 \%, 1.16 \%$ and $0.57 \%$ respectively, i.e. more than System $1(1.38 \%, 0.85 \%, 0.41 \%)$. This is because in these decile groups we find the families with two earners who under the baseline 2010 system would no longer qualify for Family Benefits.

\section{FIGURE 5 HERE}

\section{Effects of reforms on employment incentives}

In this Section we present the effects of the analysed reforms on labour market incentives at the extensive margin, i.e. on the incentive to take up or to leave the job by parents. We focus on incentives of parents in couples, and analyse them by looking at changes in the replacement ratios (RRs) of first and second earners. For the analysis presented in this section we focus on a subsample of the data and use only the couples where both partners are defined as "labour market flexible" (LM-flexible). A labour market flexible person is someone who is not a student, does not receive disability or retirement pensions, is aged between 18-59 and is not self-employed. This sample includes 10,109 couples with children. One ought to note here that financial incentives to work which we focus on here are only one of several important factors which determine parental employment. For a more complete picture of possible consequences of the reforms on labour market one would have to examine other factors, including labour market and institutional constraints. Among the latter availability of formal and informal childcare is clearly an important element affecting labour market behaviour of parents, and in particular employment 
of both parents. However, since childcare cost is often an important barrier when it comes to employment in particular of second earners, financial reward to work will affect the combination of the employment and childcare use choices (Brewer et al. 2006, Myck and Reed, 2006). ${ }^{11}$

\section{Measuring incentives at the extensive margin}

For the couples in the subsample we compute three sets of family-level incomes, conditional on employment either of the first earner (who is the person with higher expected earnings in a couple) or of both partners:

- $Y_{(1,1)}$ for the scenario where both partners are employed (full-time);

- $Y_{(1,0)}$ for the scenario where the first earner is employed (full-time);

- $Y_{(0,0)}$ for the scenario where both partners are not employed.

This allows us to compute replacement ratios for the first earner (RR1) and the second earner (RR2) for each of the analysed tax and benefit systems (S):

$$
\begin{aligned}
& R R_{S, j}^{1}=Y^{S}{ }_{j(0,0)} / Y^{S}{ }_{j(1,0)} \\
& R R_{S, j}^{2}=Y^{S}{ }_{j(1,0)} / Y^{S}{ }_{j(1,1)}
\end{aligned}
$$

Replacement ratios are computed for the baseline tax and benefit system (Base) and for all five reform systems (Systems 1-5). The results of the calculations are presented as the difference between the Base system (0) and the reform systems (R). The effects of the reforms on the first and second earners are thus computed as:

$$
\begin{aligned}
& \Delta R R_{0 R j}^{1}=R R_{0, j}^{1}-R R_{R, j}^{1} \\
& \Delta R R_{0 R j}^{2}=R R_{0, j}^{2}-R R_{R, j}^{2}
\end{aligned}
$$

\footnotetext{
${ }^{11}$ Poland has a significantly lower formal childcare enrollment rate for preschool children compared to the EU average (43\% compared to $84 \%$ in 2011). This is partly related to historically low number of childcare places in "collective childcare structures", the popular use of informal childcare by family members or nannies and closing of a significant number of childcare facilities after 1989 (Heiner and Wator, 2006, Kamińska, 2003). Several important improvements in childcare availability have been implemented since 2006, including liberalization of childcare provision and development of childcare infrastructure (Swianiewicz, 2012). As the result, the share of preschool children has grown systematically since 2006.
} 
Positive values of these differences will imply improvements in labour market incentives and reflect either an increase in income from work or a reduction of out of work income. Negative values reflect weaker incentive to take up a job or, alternatively, higher incentives to drop out of employment. In Figure 6 we present kernel densities of changes in RRs for first earners (Figures 6A, 6C and 6E) and for second earners $(6 \mathrm{~B}, 6 \mathrm{D}, 6 \mathrm{~F})$ for all of the five reform systems. These distributions illustrate the labour market effects of the reforms and demonstrate the relative magnitude of changes under different reformed regimes. Since only some of the families in the sample are affected by the modelled changes, for clarity of exposition we present the figures only for those for which the reforms imply a change in incentives (the number of families in the sample affected by each reform is given in the Figures).

Table 5 gives the details of the proportion of families in the sample of couples with two LSflexible partners affected by the simulated changes in the positive and negative way. The results presented in Table 5 reflect the nature of the simulated changes and their implications demonstrated in Figures 3 and 4.

\section{TABLE 5 HERE}

\section{FIGURE 6 HERE}

Financial incentives for first earners improve under System 1, with the introduction of the 55\% withdrawal taper, for $20.3 \%$ of the modelled families and under System 3, where the taper is combined with a lower eligibility threshold, for $16.1 \%$ of couples. The mean changes in the RRs for families who are affected by these reforms are 0.95 percentage points (pp) and 0.58pp respectively. About 3\% of families see their first earner incentives worsened under System 3 which reflects the lower withdrawal threshold for Family Benefits. A higher value of the Child Tax Credit (System 4) increases incentives to work for first earners in 52.9\% of the families, but as we can see in Figure 6E, because of the small changes in the values the credit the differences in work incentives are in most cases very small. The mean value of the change in the RRs is 0.08pp. Increasing the value of the Family Allowance under System 2 (Figure 6C) has a negative effect on first earner incentives, as the reform increases out of work income in the scenario when none of the parents are employed. This change affects first earner incentives of about $72.4 \%$ of families, with the substantial average change in RRs of about 1.4pp. In the case of this reform the unaffected couples either have dependent children whose age makes them ineligible for Family 
Benefits, are cohabiting couples in which case the parents are treated separately for the eligibility to Family Benefits, or have high out of work incomes, which makes them ineligible for Family Benefits regardless of the work status of the parents. Since under System 5 the additional CTC premium is limited to second earners the reform has no effect on first earner incentives. In Table 5 we can also see reflection of the features of the Polish tax and benefit system which allows for situations where higher income from work or from Family Benefits can lead to a reduction in the family disposable income (through point withdrawal of Family Benefits and other means tested transfers). This is reflected in the small number of families where incentives to work worsen under Systems 1 and 4, and improve under System 2.

The picture for second earner incentives is much more complex and demonstrates the trade-offs between providing higher incentives to first and to second earners in couples. Introduction of the withdrawal taper (System 1) makes work more attractive for almost 20.3\% of first earners. However, the fact that it leads to increases in out of work incomes for second earners, implies a reduction in their financial incentives to work in the case of $12.5 \%$ of families, and results in the mean reduction of RRs for the affected families of over 3pp (Figure 6B). Work becomes more attractive in the case of this reform only for $2.3 \%$ of second earners. This contrasts with the reform under System 3, which extends eligibility to Family Benefits for two-earner couples and leads to improvements in second-earner work incentives for $8.2 \%$ of families in the sample and an overall increase in second earner work incentives of about 1pp. Because many of the families lose their entitlement to Family Benefits when the first earner works full time, the out of work income of the majority of second earners is unaffected by the increase in the level of the Family Allowance. Thus the System 2 reform worsens second earner incentives only in the case of 9.6\% of the families. As in the case of first earners the mean change in RRs of second earners at 1.5pp is quite substantial.

A similar pattern of changes to work incentives as in System 1 can be observed for the increase in the value of the Child Tax Credit (System 4). Higher incomes in one-earner scenarios imply improvements in work incentives for first earners. This however leads to worsened incentives for second earners in $51.2 \%$ of the families. At the same time, though, since some of the families do not take full advantage of the CTC in the one-earner scenario, they actually gain from the increased CTC only if both parents are working (as in the example in Figure 4B). This is the case 
in $37.6 \%$ of the families in our sample, with the resulting average effect on replacement ratios among the families affected by this reform of about 0.1pp. The design of the reform in System 5, implies only improvements in the work incentives of the second earners. Moreover, since the reform affects only $43.7 \%$ of the couples in the sample given the requirement regarding the level of earnings, those families who are affected see a relatively strong effect on their incentives to work of about $1 \mathrm{pp}$.

\section{FIGURE 7 HERE}

\section{FIGURE 8 HERE}

The results of changes in RRs are presented once again in Figures 7 and 8 from the perspective of the distribution of incentives in the baseline system. The figures show average changes in RRs for first and second earners respectively by centiles of the baseline distribution of replacement ratios with lowest values of RRs implying strongest incentives and highest values reflecting weakest incentives. This approach provides evidence on the third of the analysed trade-offs. The pattern which emerges from Figures 7 and 8 reflects to some extent the distributional effects of the reforms (Figure 5). This is because richer families are usually those with high labour market incomes and thus low RRs, while poorer families face weaker incentives given their low actual (or potential) earnings, and thus face higher replacement ratios.

As we can see in Figure 7 Systems 1 and 3 increase financial incentives to work for first earners among those with relatively weak incentives - the noticeable positive effects of Systems 1 and 3 start at about the $50^{\text {th }}$ and $60^{\text {th }}$ percentile of the baseline RR distribution, and are highest at about $75^{\text {th }}$ percentile. The effects are then reduced because families with weakest work incentives receive Family Benefits both in and out of work. This effect also explains why the negative effects of introducing System 2 are smaller among those with high levels of baseline RRs. These effects, however, are quite substantial throughout the distribution of first earner incentives. The same cannot be said of the positive effects of System 4. Although the effects are positive across the distribution of the baseline RRs, the resulting changes in the replacement ratios are very low. The effects of System 4 on second earner incentives are also small and they are fairly evenly distributed across the distribution of second earners' RRs (Figure 8). The distribution of the effect of the modelled reforms on work incentives of second earners is particularly interesting in the case of Systems 3 and 5. The mean effect of these changes on RRs in both cases is about 
1.0pp, but the effects concentrate on those with the weakest baseline incentives in the case of System 3, and on those with strongest incentives in the case of System 5. Under System 3 the mean changes in RRs become positive beyond about $75^{\text {th }}$ percentile of the baseline RRs distribution, and are highest for the second earners from the top decile of this distribution, i.e. for the $10 \%$ of families where second earner incentives are weakest. This group of second earners is also most strongly affected by the negative consequences of increasing the value of the Family Allowance under System 2.

\section{Conclusion - family support and its trade-offs}

Reducing child poverty and increasing parental employment belong to the most important policy objectives of many governments, in particular in countries which due to low fertility rates face substantial demographic imbalances in the coming decades. Using data from Poland and simulated policy reforms of the system of financial support for families with children we demonstrated that realising both of these objectives is a complex task, in particular given financial constraints faced by governments as a result of the economic slowdown. The most important trade-offs related to the support of low-income families and its consequences on the labour market have been known for long (e.g. Duncan and Giles, 1996; Blundell et al. 2000). This paper, however, sheds new light on the problem and extends the analysis of the trade-offs involved to issues which have so far been little examined.

Poland has one of the highest rates of child poverty in Europe and its female employment rates lag behind many EU countries. At the same time its level of spending on means-tested financial support for children is among the lowest (Levy et al., 2009) and the system of taxes and benefits contains no support elements conditional on labour market activity and in particular no instruments designed to make work pay for second earners in couples. It is difficult to imagine significant improvements in the material situation of families with children in Poland and other countries of the region facing similar challenges (e.g. Bulgaria, Latvia or Romania) without increases in the generosity of family-related benefits. We argue that given the complex nature of consequences which financial support for children carries with it, this will pose significant challenges to policy makers. 
Apart from the well-established trade-off between equity and labour market concerns, this paper draws the attention to the need to balance out first and second earner work incentives as well as incentives by the degree of existing financial motivation to work. As a benchmark for the analysed changes we used the introduction of tapered withdrawal of Family Benefits in place of the existing point withdrawal. This reform (System 1) would cost about 1bn PLN per year and would increase the total value of Family Benefits by about 14\%. The equity and labour market implications of this change have been compared to four other potential reforms including two to the system of Family Benefits and two to the generosity of the Child Tax Credit. All four have been calibrated to cost as much as the benchmark reform and their consequences have been analysed from the overall distributional perspective and from the point of view of labour market incentives for a sample of couples with children.

Reforms on the two extremes of the distributional spectrum, namely an increase in the level of Family Benefits (System 2) and a Child Tax Credit bonus for two-earner couples (System 5) result in very different incentive effects. The former significantly weakens incentives of both first and second earners in couples, while the second, which specifically directs resources at second earners, produces important improvements in incentives to work for second earners. As we showed in Section 5, however, these gains focus on the part of the spectrum of the baseline distribution of work incentives where these are already strong. This contrasts with a reform in which a two-earner "bonus" is created as part of Family Benefits (System 3). This system increases the generosity of in-work support for first earners in couples in a similar way to the benchmark reform (System 1). At the same time, however, it improves attractiveness of work for second earners by raising the level of income from which benefits are withdrawn for couples in which both partners are working. This arrangement balances out the negative influence on second earner incentives of the income effect of making work more financially attractive for first earners, which does not happen under the benchmark System 1. Moreover, we demonstrate that trying to increase work incentives through higher levels of the Child Tax Credit available to families (System 4) would have positive effect on work incentives of a large number of families, in particular on first earners in couples. The flip-side of this effect would be some negative incentive effects on second earners, but generally both types of effects would be very low given the assumed cost restriction of the modelled reforms. 
Naturally, there is an endless number of ways in which a billion PLN can be spent on families with children. As we argued above each type of reform will have a complex set of consequences on household incomes and incentives to work for parents. The breakdown of employment pattern by family types presented in Section 3 suggests that from the point of view of increasing labour market activity family support policy should focus on trying to make work pay for second earners in couples, most of whom are women. Simulation of System 3 demonstrated that this can be done in such a way as to balance out incentives for first earners and provide strong incentives to those second earners who currently face weakest incentives to work. At the same time resources would be directed to families in the lower half of the income distribution which could result in direct reduction of child poverty.

The analysis presented in this paper shows a broad range of consequences of different types of reforms to the system of financial support for families with children and the trade-offs between them. Each of the analysed changes implies different distributional effects and varies in the consequences concerning work incentives for first and second earners. Moreover, these labour market effects may affect different segments of the baseline distribution of employment incentives which would influence their actual impact. It is policy makers who have to define objectives and follow this with policy implementation. Understanding of the complexity of consequences involved in family policy is crucial if the aim is to "kill two birds with one stone" (Bargain and Orsini, 2006), namely to reduce poverty and improve incentives to work. At the time of a long lasting economic slowdown and tight government budgets reaching this aim may be more important than ever. 


\section{TABLES}

Table 1. Families of working age partners by number of children and partnership status

Proportion $\begin{gathered}\text { Number of } \\ \text { observations }\end{gathered}$

$\begin{array}{ccc}\text { With children } & 0.444 & \mathbf{1 6 5 3 3} \\ -\quad \text { lone parents } & 0.064 & 2,446 \\ -\quad \text { couples } & 0.380 & 14,087 \\ \text { Without children } & & \\ \text { - singles } & 0.556 & \mathbf{2 1 4 8 7} \\ -\quad \text { couples } & 0.376 & 13,690 \\ & 0.180 & 7,797\end{array}$

Total

$\mathbf{3 8 , 0 2 0}$

Source: Authors' calculations based on the PHBS 2010 data. Weighted proportions using weights provided by the CSO.

Table 2. Employment rates by family types

\begin{tabular}{|c|c|c|}
\hline & Men & Women \\
\hline Singles without children & 0.617 & 0.571 \\
\hline Lone parents & 0.701 & 0.684 \\
\hline Couples without children & 0.696 & 0.595 \\
\hline Couples with children & 0.890 & 0.676 \\
\hline
\end{tabular}

Table 3. Employment of parents in the families with children according to the fact of receiving or not receiving family benefits

\begin{tabular}{|c|c|c|}
\hline Families: & Without family benefits & With family benefits \\
\hline Couples (n.obs.): & $\mathbf{1 0 8 1 7}$ & $\mathbf{3 2 7 0}$ \\
$-\quad$ both working & 0.678 & 0.392 \\
\hline - $\quad$ only father works & 0.230 & 0.449 \\
\hline - $\quad$ only mother works & 0.062 & 0.082 \\
\hline both not working & 0.031 & 0.077 \\
\hline Lone mothers (n.obs): & & $\mathbf{7 2 0}$ \\
\hline - working & $\mathbf{1 5 0 2}$ & 0.472 \\
\hline$\quad$ not working & 0.803 & 0.528 \\
\hline
\end{tabular}

Source: Authors' calculations based on the PHBS 2010 data. Weighted proportions using weights provided by the Polish CSO. 
Table 4. Improving incentives to work for families with children: reform scenarios

\begin{tabular}{|c|c|c|c|c|c|c|c|}
\hline \multirow[b]{2}{*}{$\begin{array}{c}\text { Policy } \\
\text { name }\end{array}$} & \multicolumn{3}{|c|}{ Changes in basic policy: } & \multirow[b]{2}{*}{$\begin{array}{c}\text { FB } \\
\text { taper }\end{array}$} & \multicolumn{3}{|c|}{ Double earner couples: } \\
\hline & $\begin{array}{c}\text { FB } \\
\text { thresholds }\end{array}$ & $\begin{array}{c}\text { FB } \\
\text { amounts }\end{array}$ & $\begin{array}{c}\text { CTC } \\
\text { amount }\end{array}$ & & $\begin{array}{c}\text { minimum } \\
\text { income } \\
\text { of } 2^{\text {nd }} \text { person }\end{array}$ & $\begin{array}{c}\text { FB } \\
\text { thresholds } \\
\text { extension }\end{array}$ & $\begin{array}{c}\text { CTC } \\
\text { amounts } \\
\text { extension }\end{array}$ \\
\hline System 1 & - & - & - & $55.0 \%$ & - & - & - \\
\hline System 2 & - & $+20.0 \%$ & - & - & - & - & - \\
\hline System 3 & $-9.0 \%$ & - & - & $55.0 \%$ & $\begin{array}{c}80.0 \% \\
\text { of } \mathrm{mw}^{*}\end{array}$ & $+50.0 \%$ & - \\
\hline System 4 & - & - & $+19.8 \%$ & - & - & - & - \\
\hline System 5 & - & - & - & - & $\begin{array}{l}176.5 \% \\
\text { of mw* }\end{array}$ & - & + $1 \mathrm{CTC}$ \\
\hline
\end{tabular}

Source: Authors' selection with calibration based on the SIMPL microsimulation model.

Notes: * - mw - minimum wage (1317 PLN per month).

Table 5. Effect of reforms: proportion of couples by change in work incentives

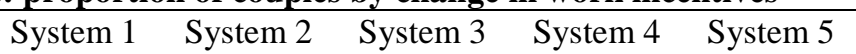

First earner incentives

$\begin{array}{llllll}\text { - worsened } & 0.007 & 0.724 & 0.034 & 0.010 & 0.000 \\ \text { - unchanged } & 0.791 & 0.240 & 0.805 & 0.461 & 1.000 \\ \text { - improved } & 0.203 & 0.037 & 0.161 & 0.529 & 0.000 \\ & & & & & \\ \text { Second earner incentives } & & & & & \\ \text { - worsened } & 0.125 & 0.096 & 0.077 & 0.512 & 0.000 \\ \text { - unchanged } & 0.852 & 0.901 & 0.841 & 0.113 & 0.563 \\ \text { - improved } & 0.023 & 0.003 & 0.082 & 0.376 & 0.437\end{array}$

Source: Authors' calculations using the SIMPL model based on the PHBS 2010 data.

Notes: Based on the sample of couples with two LS-flexible partners. 


\section{FIGURES:}

Figure 1. Gross income and family support -2010

\section{A - Budget constraint}

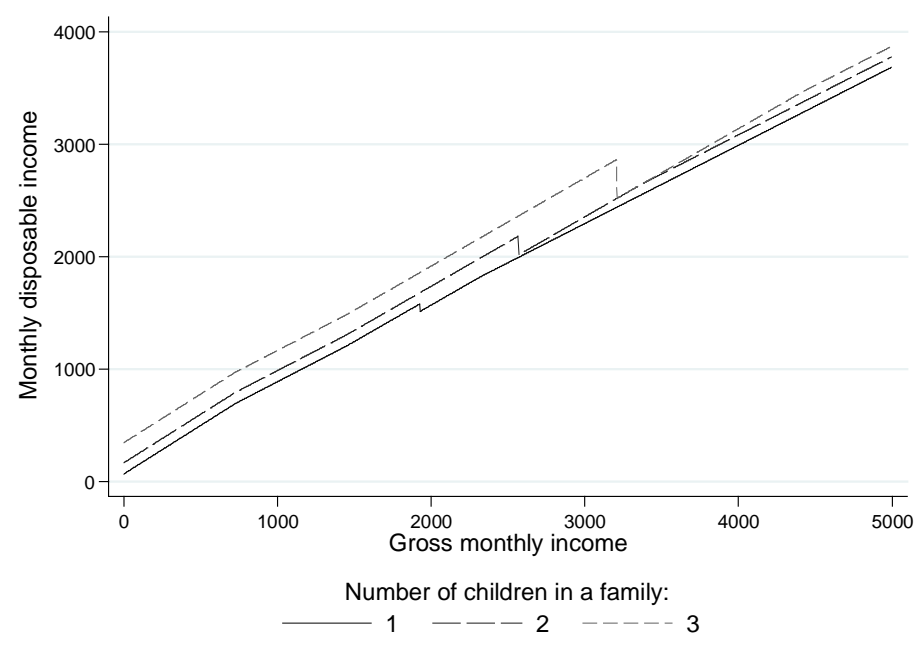

B - Total family support

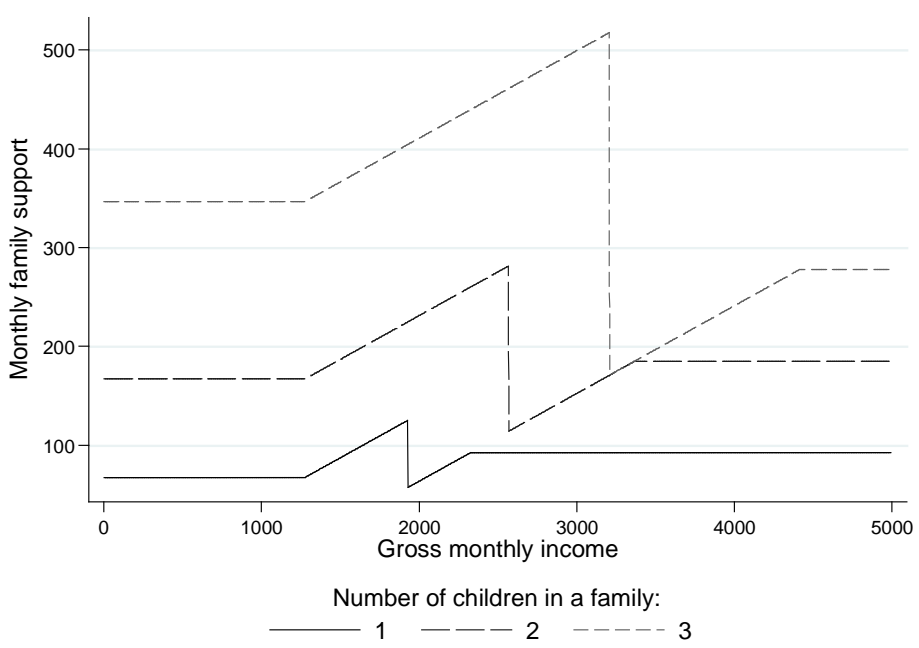

Source: Authors' calculations using the SIMPL microsimulation model (V4S3_12).

Figure 2. Employment rates by family type, age and age of youngest child

A. Men and women in couples

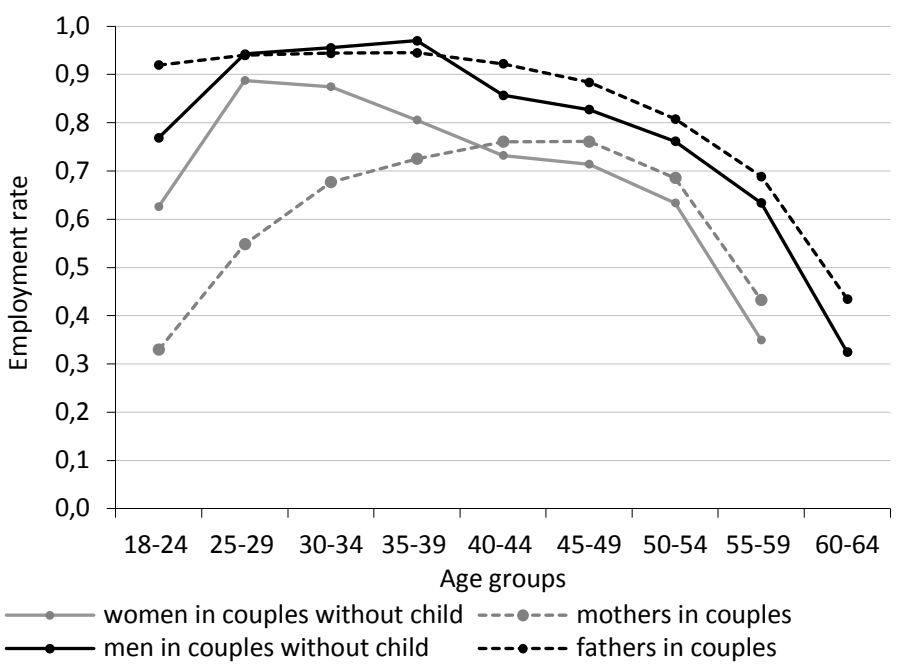

B. Parents by age of youngest child

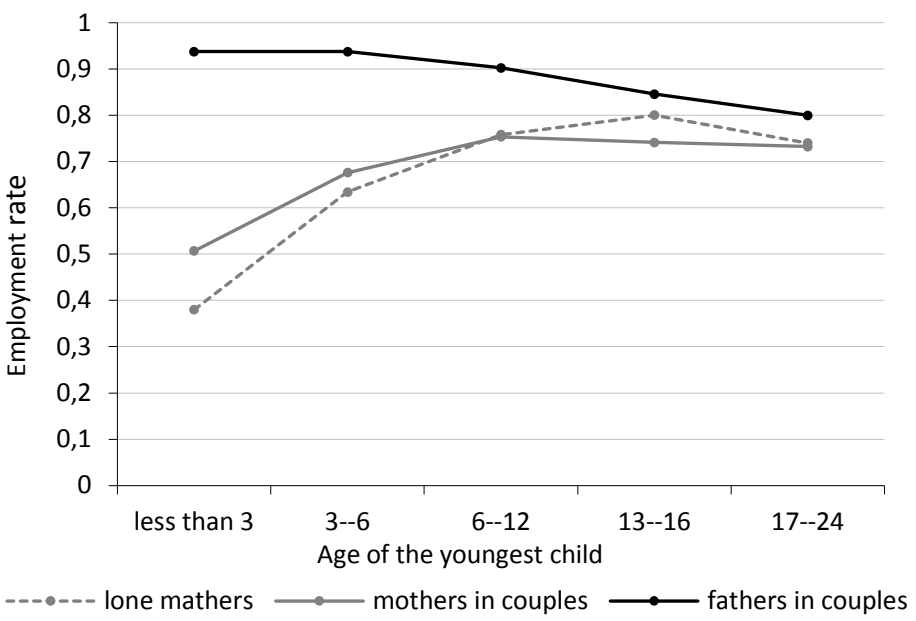

Source: Authors' calculations based on the PHBS 2010 data. 
Figure 3. Monthly family benefits in a single \& double earner family: baseline (System 0 ) and Systems 1-3

A. Single earner family with two children:

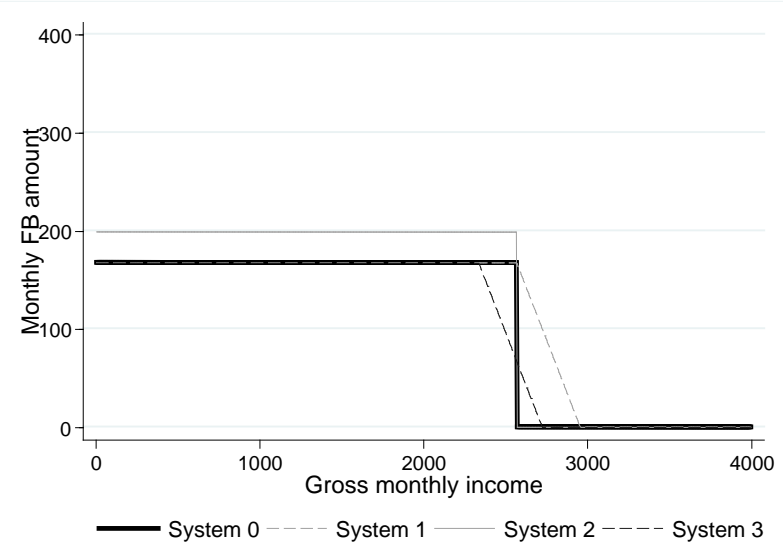

B. Double earner family with three children (1st earner on wage at $75 \%$ of mean wage):

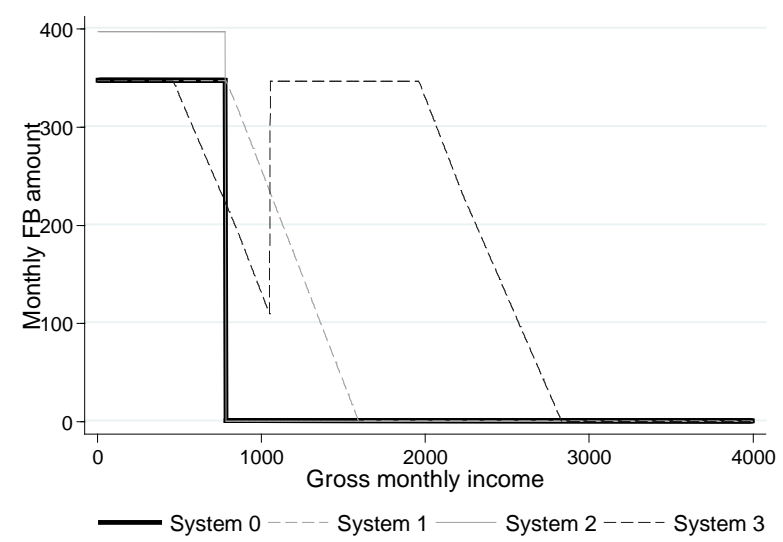

Source: Authors' calculations using the SIMPL microsimulation model (V4S3_12).

Notes: The assumed gross monthly minimum wage at 2010 level (1,317 PLN); the gross monthly mean wage in 2010 was 3,224.98 PLN.

Figure 4. Monthly CTC amount in a single \& double earner family: baseline (System 0) and Systems 4 and 5

A. Single earner family with two children:

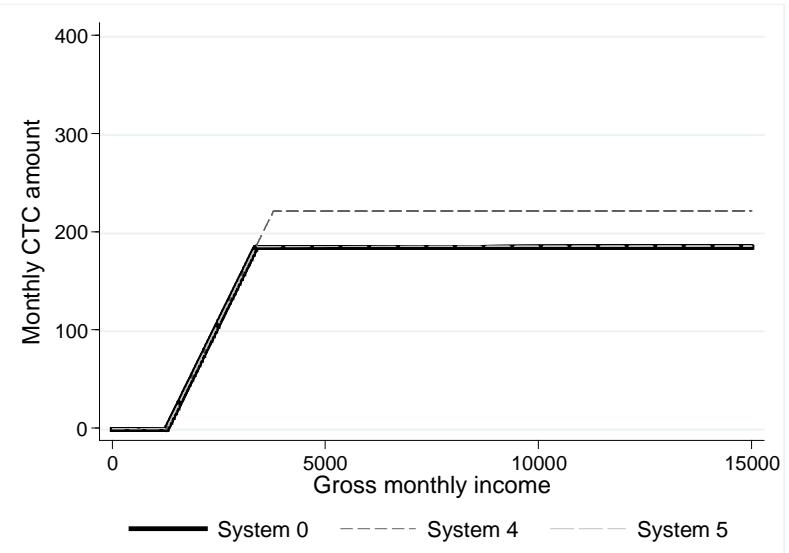

B. Double earner family with two children

$\left(1^{\text {st }}\right.$ earner on wage at $75 \%$ of mean wage)

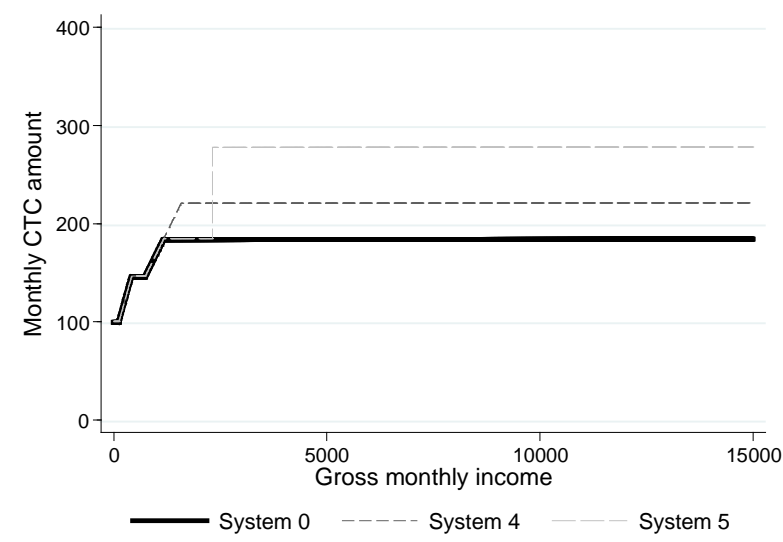

Source: Authors' calculations using the SIMPL microsimulation model (V4S3_12).

Notes: The assumed gross monthly minimum wage at 2010 level (1,317 PLN); the gross monthly mean wage in 2010 was 3,224.98 PLN. 
Figure 5. Distributional consequences of modelled reforms

A. Reforms to Family Benefits

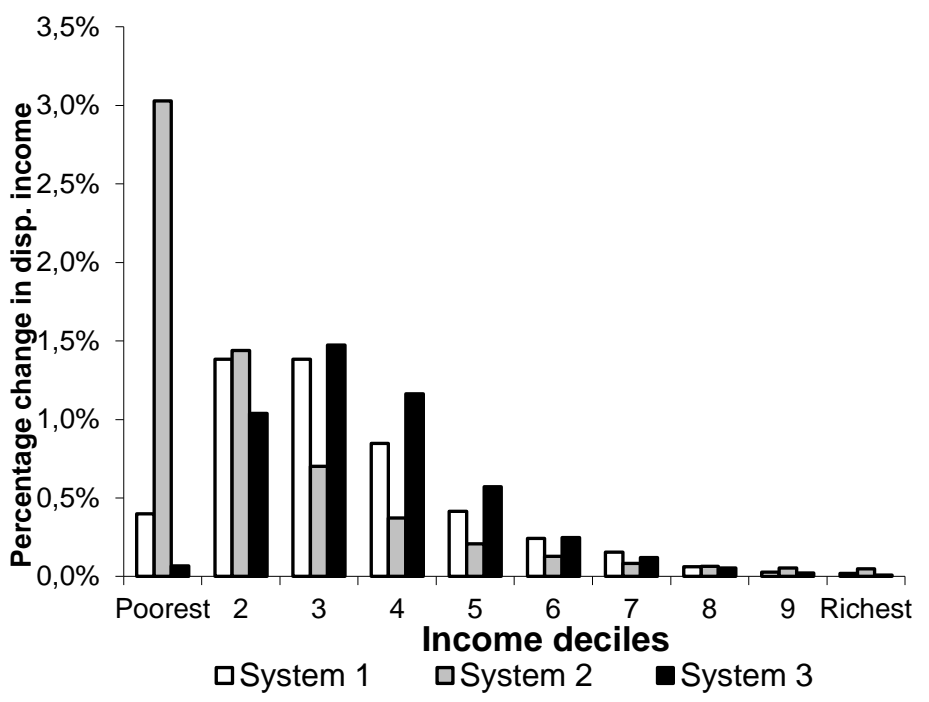

B. Reforms to Child Tax Credit

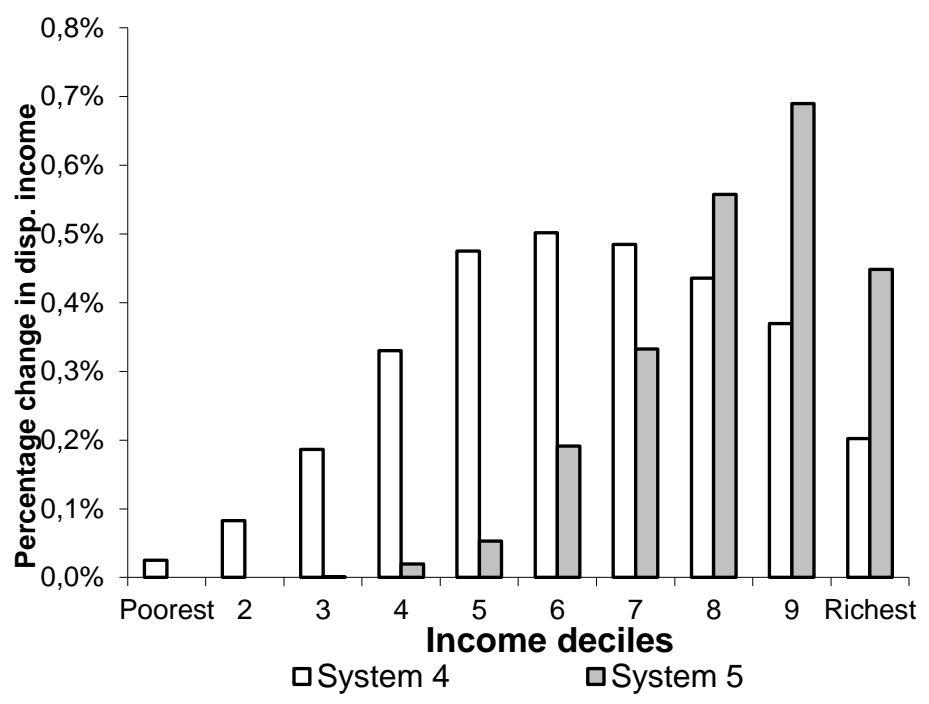

Source: Authors' calculations using the SIMPL microsimulation model (V4S3_12) on PHBS 2010 data. Notes: Reference system: Baseline 2010; average figures per decile computed for households with children. 
Figure 6. Changes in RRs resulting from modelled reforms

A) Systems 1 and 3: first earners

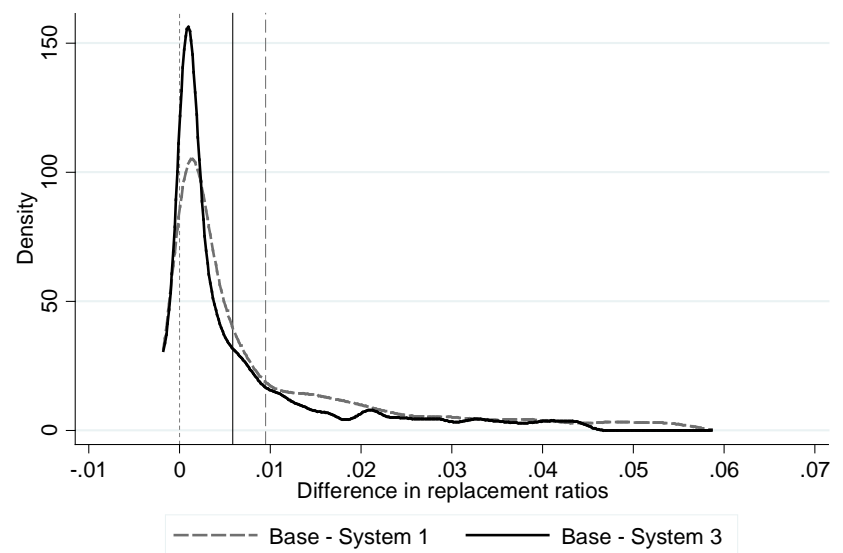

Number of families: System 1: 1967 System 3: 1767

C) System 2: first earners

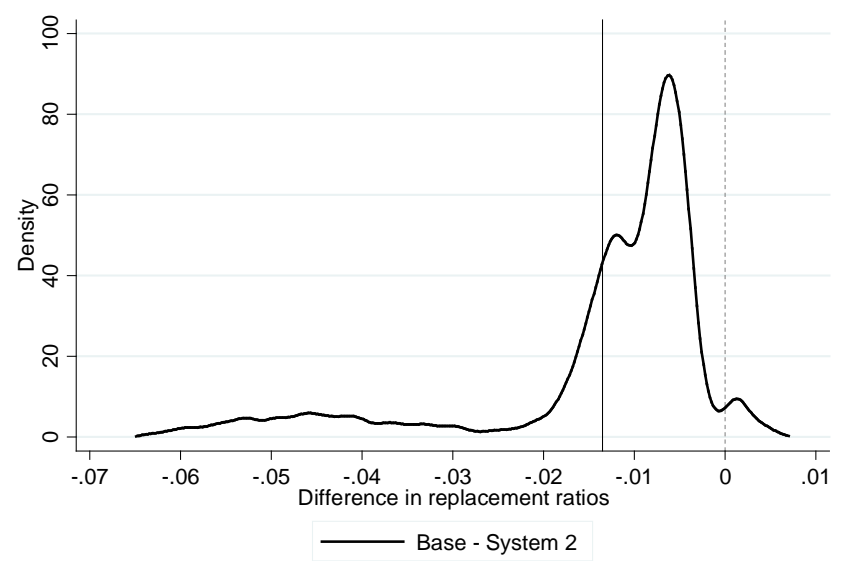

Number of families: 7467

E) System 4: first earners

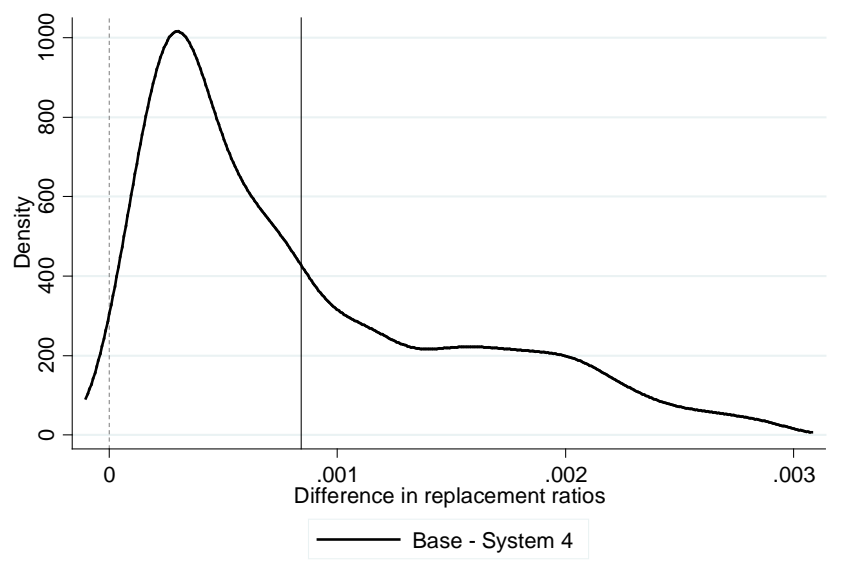

Number of families: 5129
B) Systems 1 and 3: second earners

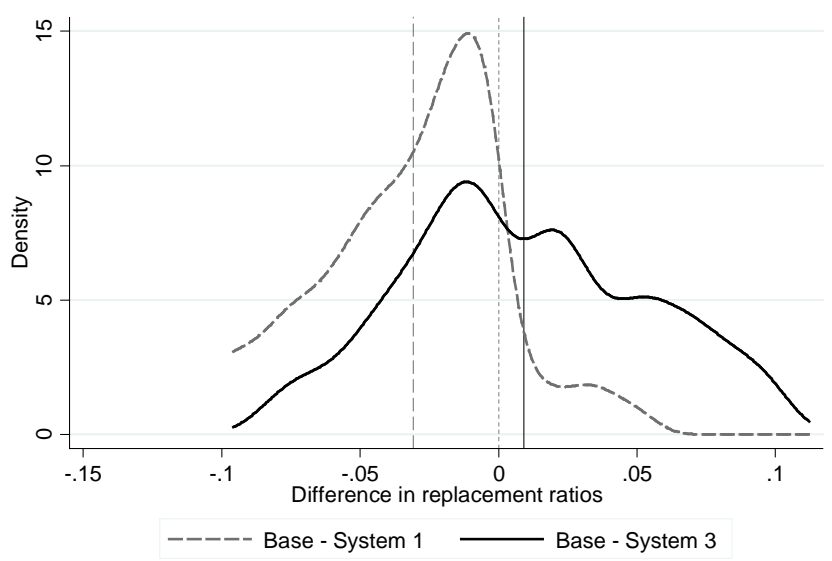

Number of families: System 1: 1338 System 3: 1417

D) System 2: second earners

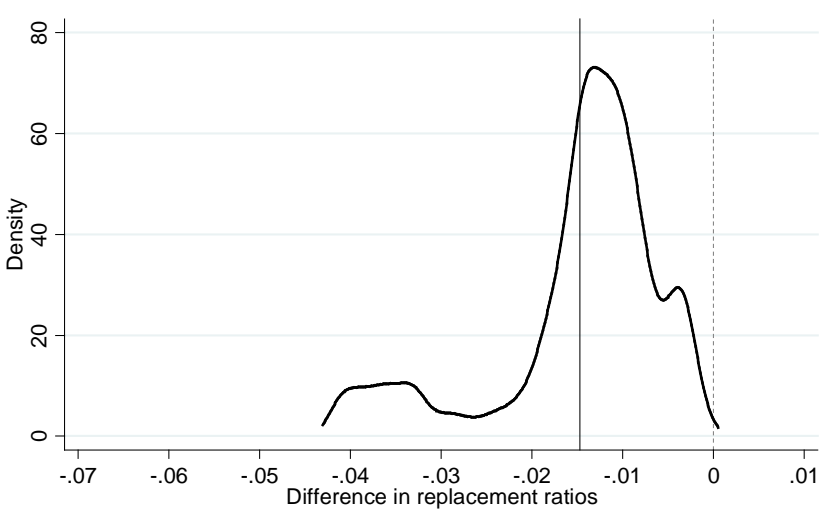

Base - System 2

Number of families: 855

F) Systems 4 and 5: second earners

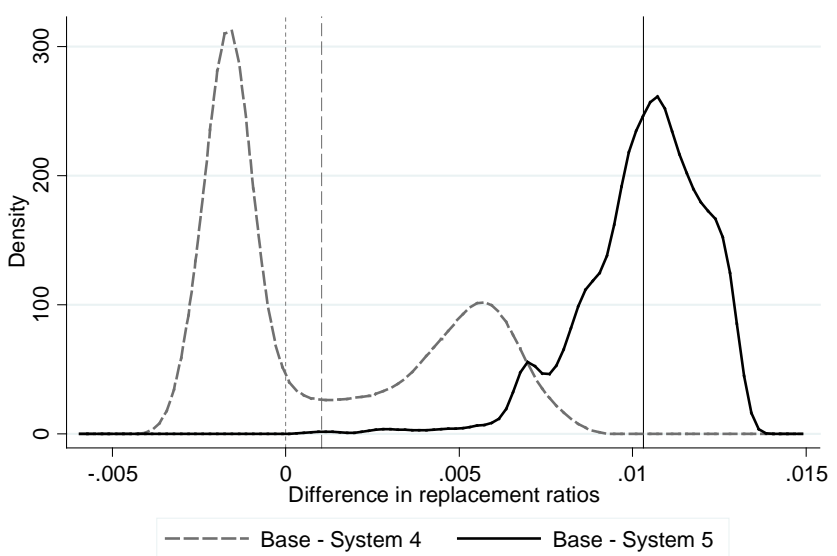

Number of families: System 4: 8792 System 5: 4020

Source: Authors' calculations using the SIMPL microsimulation model (V4S3_12) on PHBS 2010 data. Notes: Based on the sample of couples with two LM-flexible partners. For clarity of exposition figures drawn excluding outliers below $1^{\text {st }}$ percentile and above $99^{\text {th }}$ percentile of the distribution of changes in RRs. Kernel densities presented only for the subsample of couples for which incentives change as a result of the simulated reform. Number of families included specified on each figure. 
Figure 7. Changes in RRs by baseline work incentives - first earners

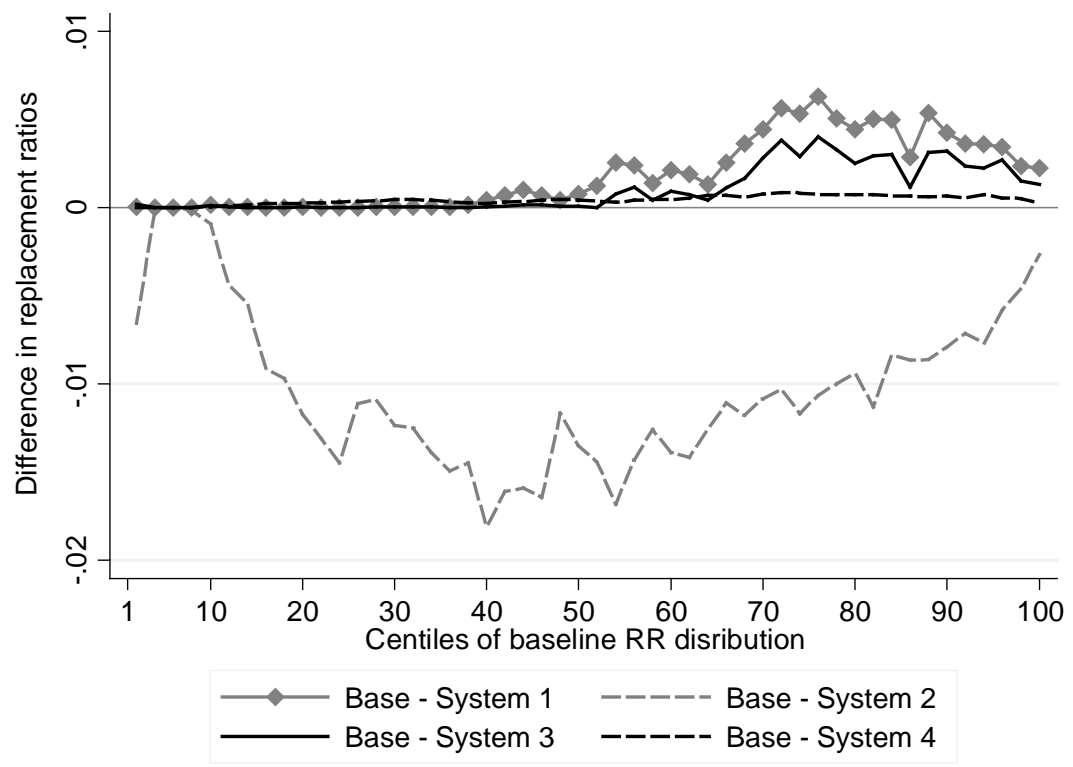

Source: Authors' calculations using the SIMPL microsimulation model (V4S3_12) on PHBS 2010 data. Notes: Based on the sample of couples with two LS-flexible partners. For clarity of exposition averages computed for two adjacent centiles excluding outliers below $1^{\text {st }}$ percentile and above $99^{\text {th }}$ percentile of the distribution of changes in RRs.

Figure 8. Changes in RRs by baseline work incentives - second earners

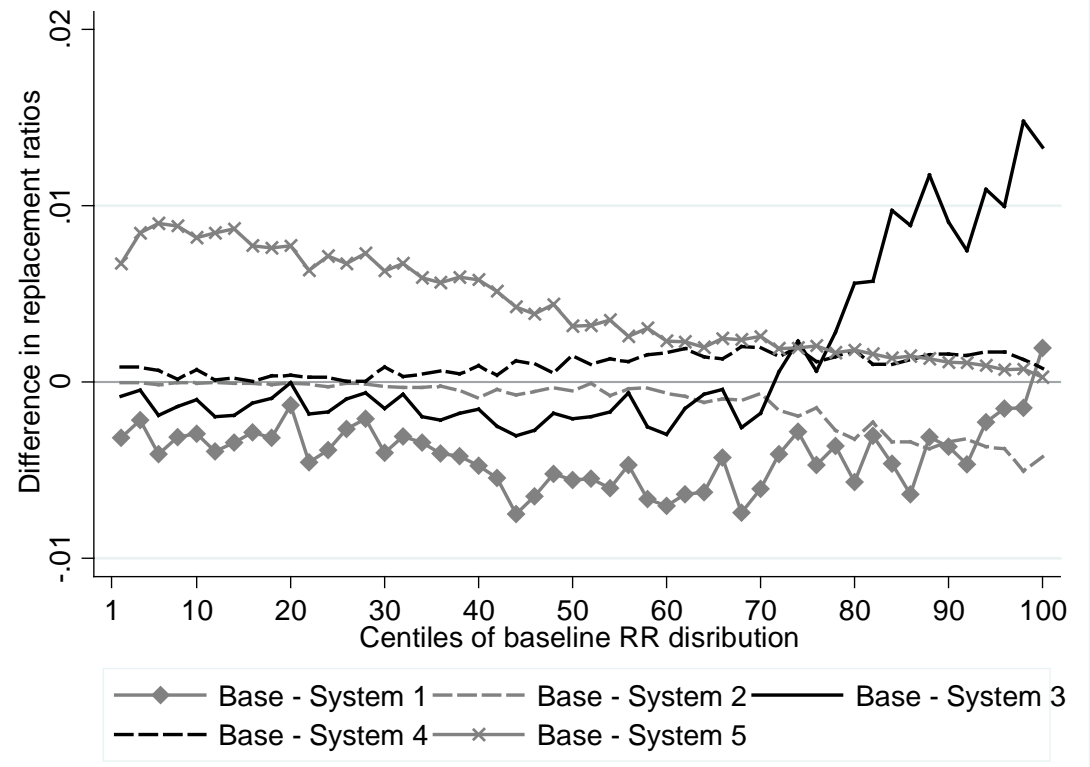

Source: Authors' calculations using the SIMPL microsimulation model (V4S3_12) on PHBS 2010 data. Notes: Based on the sample of couples with two LS-flexible partners. For clarity of exposition averages computed for two adjacent centiles excluding outliers below $1^{\text {st }}$ percentile and above $99^{\text {th }}$ percentile of the distribution of changes in RRs. 


\section{Appendix}

Table A1. Family Benefits in 2010 (in PLN per month)

\begin{tabular}{lc}
\hline & $\begin{array}{c}\text { 2010 system: } \\
\text { (January to October) }\end{array}$ \\
$\begin{array}{l}\text { Income criterion } \\
\text { Income criterion when there is a disabled child }\end{array}$ & 504 \\
in family & 583 \\
& \\
Family allowance per child: & \\
- child aged 0-4 & 68 \\
- child aged 5-17 & 91 \\
- child aged 18 and more & 98 \\
& \\
Main supplements: & \\
- lone parent supplement & \\
a) amount per child & 170 \\
b) amount per child if child is disabled & 250 \\
- for parents on unpaid maternal leave & 400 \\
- for families with more than 2 children & 80 \\
- school year start (one per year) & 100 \\
- child birth supplement & 1000 \\
& \\
Nursing allowance & \\
Income criterion & - \\
Amount of allowance & 520 \\
Nursing benefit & \\
Universal child birth benefit & 153 \\
\hline Source: Minisy of Labour and Social Aftars. & 1000 \\
\hline
\end{tabular}

Source: Ministry of Labour and Social Affairs.

Table A2. Families with dependent children by number and age of children

Total Couples Lone mothers

Number of children:

$\begin{array}{lllll}- & 1 & 0.472 & 0.446 & 0.627 \\ - & 2 & 0.372 & 0.389 & 0.264 \\ - & 3 & 0.112 & 0.118 & 0.078 \\ - & 4+ & 0.045 & 0.047 & 0.032\end{array}$

Age of youngest child

\begin{tabular}{|c|c|c|c|}
\hline$-\quad<3$ & 0.216 & 0.230 & 0.149 \\
\hline $3-6$ & 0.194 & 0.198 & 0.179 \\
\hline 7-12 & 0.230 & 0.229 & 0.233 \\
\hline $13-16$ & 0.168 & 0.163 & 0.193 \\
\hline $17-24$ & 0.193 & 0.181 & 0.250 \\
\hline ber of observations & 16,533 & 14,087 & 2,222 \\
\hline
\end{tabular}

Source: Authors' calculations based on the PHBS 2010 data.

Notes: Lone fathers excluded from the detailed breakdown (there are only 224 lone fathers in the families of working age parents sample). 
Table A3. Employment of parents in the families according to the number or the age of children and receipt of family benefits

\begin{tabular}{|c|c|c|c|c|c|c|c|c|}
\hline \multirow{3}{*}{ Types of families } & \multicolumn{4}{|c|}{ Families not receiving family benefits } & \multicolumn{4}{|c|}{ Families receiving family benefits } \\
\hline & \multicolumn{2}{|c|}{ number of children } & \multicolumn{2}{|c|}{ age of youngest child } & \multicolumn{2}{|c|}{ number of children } & \multicolumn{2}{|c|}{ age of youngest child } \\
\hline & 1 or 2 & $3+$ & 6 or less & $6+$ & 1 or 2 & $3+$ & 6 or less & $6+$ \\
\hline Couples (n.obs.): & 9702 & 1115 & 4092 & 6725 & 2175 & 1095 & 1794 & 1476 \\
\hline Both working: & 0.673 & 0.713 & 0.649 & 0.695 & 0.348 & 0.479 & 0.322 & 0.475 \\
\hline Only father works: & 0.229 & 0.234 & 0.314 & 0.179 & 0.473 & 0.401 & 0.567 & 0.306 \\
\hline Only mother works: & 0.064 & 0.038 & 0.025 & 0.084 & 0.090 & 0.067 & 0.052 & 0.119 \\
\hline Both not working: & 0.033 & 0.015 & 0.013 & 0.042 & 0.089 & 0.054 & 0.059 & 0.100 \\
\hline Lone mothers (n.obs.) & 1438 & 64 & 1132 & 370 & 572 & 148 & 420 & 300 \\
\hline Working & 0.799 & 0.891 & 0.673 & 0.845 & 0.479 & 0.446 & 0.357 & 0.555 \\
\hline Not working & 0.201 & 0.109 & 0.327 & 0.155 & 0.521 & 0.554 & 0.643 & 0.445 \\
\hline
\end{tabular}

Source: Authors' calculations based on the PHBS 2010 data. 


\section{References:}

Adam S., M. Brewer and A. Shephard (2006) Financial Work Incentives in Britain: Comparisons Over Time and Between Family Types, Institute of Fiscal Studies Working Paper 06/20, London.

Adam S. and J. Browne (2010) Redistribution, Work Incentives and Thirty Years of UK Tax and Benefit Reform, Institute of Fiscal Studies Working Paper 10/24, London.

Bargain O. and K. Orsini (2006) In-Work Policies in Europe: Killing two Birds with one Stone? Labour Economics, vol. 13 (6), pp. 667-693.

Bargain O., L. Morawski, M. Myck and M. Socha (2007) “As SIMPL as that - introducing a Tax-Benefit Microsimulation model for Poland”, IZA Discussion Paper 2988, Bonn.

Blundell R. (2001) Welfare reform for low income workers, Oxford Economic Papers, vol. 53, pp. 189-214.

Blundell R., A. Duncan, J. McCrae and C. Meghir (2000) The Labour Market Impact of the Working Families’ Tax Credit, Fiscal Studies, vol. 21(1), pp. 75-104.

Brewer M., A. Duncan, A. Shephard and M.-J. Suarez (2006) “Did Working Families’ Tax Credit Work? The Impact of In-Work Support on Labour Supply in Great Britain”, Labour Economics, vol. 13, pp. 699-720.

Björklund A. (2006) Does family policy affect fertility? Journal of Population Economics, vol. 19 (1), pp. 3-24.

Clark T., A. Dilnot, A. Goodman, and M. Myck (2002) Taxes and Transfers, Oxford Review of Economic Policy, vol.18 (2), pp. 187-201.

Dearing H., H. Hofer, C. Lietz, R. Winter-Ebmer and K. Wrohlich (2007) Why do mothers work longer hours in Austria than in Germany? A comparative microsimulation study. Fiscal Studies, vol. 28(4), pp. 463-495.

Domitrz A., M. Myck, L. Morawski, A. Semeniuk (2013) Dystrybucyjny wpływ reform podatkowo-świadczeniowych wprowadzonych w latach 2006-2011, Bank i Kredyt, vol. 44(3), pp. 261-286.

Haan P., and M. Myck (2010) „Safety net still in transition: labour market incentive effects of social support in Poland and Germany“ Bank i Kredyt, vol. 41(3), pp. 5-34.

Haan P., M. Myck (2012) "Multi-family households in a labour supply model: a calibration method with application to Poland.” Applied Economics, vol. 22, pp. 2907-2919. 
Haan P. and K. Wrohlich (2011) Can Child Care Encourage Employment and Fertility? Evidence from a Structural Model. Labour Economics, vol. 18 (4), pp. 498-512.

Duclos E., P. Lafebre, P. Merrigan (2001) A natural Experiment on the economics on storks: Evidence on the impact of differential family policy on fertility rates in Canada. Center of Research on Economics, Fluctuations and Employment, Working paper no. 136, Montreal and Quebec University.

Duncan, A. and C. Giles (1996) Labour Supply Incentives and Recent Family Credit Reforms, The Economic Journal, vol. 106(434), pp. 142-155.

European Commission (2010) Europa 2020. A Strategy for smart, sustainable and inclusive growth, Communication from the Commission, European Commission, Brussels.

Fiori F., F. Rinesi, A. Pinelli and S. Prati (2013) Economic Insecurity and the Fertility Intentions of Italian Women with One Child, Population Research and Policy Review, vol. 32, pp. 373-413.

Gauthier, A. H. (2007) The impact of family policies on fertility in industrialized countries: a review of the literature, Population Research and Policy Review, vol. 26, pp. 323-346.

Haan P. and M. Myck (2007) Apply with caution: introducing UK-style in-work support in Germany, Fiscal Studies, vol. 28, pp. 43-72.

Haan P., L. Morawski, and M. Myck (2008) “Taxes, Benefits and Financial Incentives to Work. the United Kingdom, Germany and Poland Compared.”, Bank i Kredyt, vol. 39 (1), pp. 533.

Heinen J. and M. Wator (2006) Child Care in Poland before, during and after Transition: Still a Women’s Business, Social Politics, vol. 2 (20) pp. 189-216.

Immervoll H. and D. Barber (2007) Can Parents Afford to Work? Childcare Costs, Tax-Benefit Policies and Work Incentives, IZA Discussion Paper nr 1932.

Immervoll H., H. Kleven, H. Kreiner, E. Saez (2007) Welfare Reform in European Countries: A Microsimulation Analysis, Economic Journal, 117 (516), pp. 1-44.

Immervoll H., H. J. Kleven, C. T. Kreiner and N. Verdelin (2011) An Evaluation of the TaxTransfer Treatment of Married Couples in European Countries, Journal of Public Economics, 95 (11-12), pp. 1485-1500.

Immervoll H., H. Sutherland, K. de Vos (2001) Reducing child poverty in the European Union: the role of child benefits, in: Vleminckx K. and Smeeding T.M. (eds.) Child well-being, 
Child poverty and Child Policy in Modern Nations. What do we know? Revised Edition; The Policy Press: Bristol.

Jara H. X., A. Tumino (2013) Tax-benefit Systems, Income Distribution and Work Incentives in the European Union, EUROMOD Working Paper No. EM 7/13, ISER, University of Essex, Colchester.

Kamińska K. (2003) Upowszechnienie edukacji przedszkolnej w Polsce: stan i prognozy na przyszłość, In: Zahorska, M. (ed), Edukacja przedszkolna w Polsce - szanse i zagrożenia, ISP, Warsaw.

Kundera M., H. Levy, M. Myck (2013) Euromod Country Report - Poland 2007-2012. ISER, University of Essex, Colchester.

Kurowska A. (2012) Wpływ wybranych instrumentów polityki rodzinnej i polityki zatrudnienia na dzietność oraz aktywność zawodową kobiet, Polityka Społeczna, vol. 11-12, pp. 14-19.

Laroque G. and B. Salanie (2008) Does Fertility Respond to Financial Incentives?, IZA Discussion Paper, nr 3575, IZA-Bonn.

Kornstad T. and T. O. Thoresen (2007) A Discrete Choice Model for Labor Supply and Child Care, Journal of Population Economics, vol. 20 (4), pp. 781-803.

Levy H., L. Morawski, and M. Myck (2009) Alternative tax-benefit strategies to support children in Poland, in Lelkes O., H. Sutherland (eds.) Tax and Benefit Policies in the Enlarged Europe: Assessing the Impact with Microsimulation Models, Ashgate, Vienna.

Matysiak A. (2011) On the interdependencies between fertility and women’s labour supply, European Studies of Population, vol. 17, Springer.

Matysiak A. and D. Vignoli (2008) Fertility and women’s employment: a meta-analysis, European Journal of Population, vol. 24(4), pp. 363-384.

Morawski L. and M. Myck (2010) ‘Klin’-ing up: Effects of Polish Tax Reforms on Those In and on those Out, Labour Economics, vol. 17(3), pp.556-566.

Morawski L. and M. Myck (2011) Distributional Effects of the Child Tax Credit in Poland and Its Potential Reforms, Ekonomista vol. 6, pp. 815-831.

Myck M., A. Domitrz, L. Morawski and A. Semeniuk (2013) Financial incentives to work in the context of a complex reform package and growing wages: the Polish experience 20052011, CenEA Working Paper, WP 1/2013, CenEA, Szczecin.

Myck M. and H. Reed (2006) "Tax and Benefit Reforems in a Model of Labour Market Transitions”, Vierteljahrshefte zur Wirtschaftsforschung (Quarterly Journal of Economic Research) vol. 75 (3), pp. 208-239. 
OECD (2011) Doing better for families, OECD Publishing, Paris.

Steiner V. and K. Wrohlich (2004) Household Taxation, Income Splitting and Labor Supply Incentives: A Microsimulation Study for Germany, CESifo Economic Studies, vol. 50, pp. 541-568.

Swianiewicz P. (eds.) (2012) Edukacja Przedszkolna, Ośrodek Rozwoju Edukacji, Warsaw. Thévenon O. and A. Luci (2012) Reconciling Work, Family and Child Outcomes. What Implications for Family Support Policies? Population Research and Policy Review, vol. 31, pp. 855-882.

Whiteford P. and W. Adema (2007) What Works Best in Reducing Child Poverty: A Benefit of Work strategy? OECD Social, Employment and Migration Woking Papers, nr 51, OECD, Paris. 